Research Article

\title{
Honey-Induced Protein Stabilization as Studied by Fluorescein Isothiocyanate Fluorescence
}

\author{
Yin How Wong, Habsah Abdul Kadir, and Saad Tayyab \\ Biomolecular Research Group, Biochemistry Programme, Institute of Biological Sciences, Faculty of Science, \\ University of Malaya, 50603 Kuala Lumpur, Malaysia
}

Correspondence should be addressed to Saad Tayyab; saadtayyab2004@yahoo.com

Received 11 July 2013; Accepted 22 August 2013

Academic Editors: H. Mobasheri and P. Pohl

Copyright (c) 2013 Yin How Wong et al. This is an open access article distributed under the Creative Commons Attribution License, which permits unrestricted use, distribution, and reproduction in any medium, provided the original work is properly cited.

Protein stabilizing potential of honey was studied on a model protein, bovine serum albumin (BSA), using extrinsic fluorescence of fluorescein isothiocyanate (FITC) as the probe. BSA was labelled with FITC using chemical coupling, and urea and thermal denaturation studies were performed on FITC-labelled BSA (FITC-BSA) both in the absence and presence of 10\% and 20\% (w/v) honey using FITC fluorescence at $522 \mathrm{~nm}$ upon excitation at $495 \mathrm{~nm}$. There was an increase in the FITC fluorescence intensity upon increasing urea concentration or temperature, suggesting protein denaturation. The results from urea and thermal denaturation studies showed increased stability of protein in the presence of honey as reflected from the shift in the transition curve along with the start point and the midpoint of the transition towards higher urea concentration/temperature. Furthermore, the increase in $\Delta G_{D}^{\mathrm{H}_{2} \mathrm{O}}$ and $\Delta G_{D}^{25^{\circ} \mathrm{C}}$ in presence of honey also suggested protein stabilization.

\section{Introduction}

Protein stability has been regarded as a critical issue in biotechnology due to increasing demands of proteins in various applications, such as industrial enzymes, analytical tools, therapeutics agents, clinical diagnostic materials, and so forth $[1-3]$. However, many proteins suffer from the drawback of poor storage and operational stability and lose their functionality and native conformation over a period of time [1]. On the other hand, various industrial processes require operational conditions such as extreme temperature, $\mathrm{pH}$, pressure, and the presence of various chemicals and solvents, which may lead to protein destabilization and denaturation. Hence, there is a need to increase the stability of proteins used in industrial processes.

Several attempts have been made to increase protein stability using chemical modification, site-directed mutagenesis, introduction of disulphide bonds, and anion binding sites as well as solvent engineering [4-7]. However, only a few modified enzymes have displayed commercial viability $[8,9]$. Solvent engineering has shown an edge over other methods of protein stabilization as osmolytes are known to be functionally and biologically compatible with most of the proteins $[2,10,11]$. Sugars and amino acids are well-known naturally occurring osmolytes, showing great protein stabilizing potential against different denaturing conditions including chemical (urea and guanidine hydrochloride) and thermal denaturations $[1,12-14]$. With a few exceptions $[12,15,16]$, most of the osmolyte-induced protein stabilization studies have been focused on using a single osmolyte $[3,13,14]$.

Honey is a natural mixture of compounds with highsugar content $(\sim 38 \%$ fructose, $\sim 32 \%$ glucose, $\sim 1.7 \%$ maltose, $\sim 1.4 \%$ sucrose, $\sim 1 \%$ turanose, $\sim 0.8 \%$ isomaltose, $\sim 0.4 \%$ erlose, etc.) and minor constituents such as amino acids, proteins, vitamins, minerals, and polyphenols $[17,18]$. Due to the presence of these compounds, honey has been regarded as the traditional medicine and food supplement since prehistorical time. Modern science has also recognized the antibacterial, antioxidant, anti-inflammatory, and wound healing properties of honey [18]. Due to the presence of a number of osmolytes, honey can be used as a potential protein stabilizer. Recently, an attempt has been made to study 
protein stabilizing potential of honey using simulated honey sugar cocktail with sugar composition similar to that found in honey [16]. Our preliminary studies (unpublished observations) have suggested that the protein stabilization studies in the presence of honey using fluorescence spectroscopy are hampered due to interference by the presence of proteins as well as other molecules in honey, which act as fluorescence quenchers. Therefore, fluorescein isothiocyanate (FITC) fluorescence has been used to study protein stabilization against urea and thermal denaturations in the presence of honey using FITC fluorescence spectroscopic signal after labelling the model protein, bovine serum albumin (BSA), with FITC.

\section{Materials and Methods}

2.1. Materials. Bovine serum albumin, essentially fatty acid free (type A-6003), fluorescein isothiocyanate, isomer I (type F-7250), and urea ultrapure (type U-0631) were purchased from Sigma-Aldrich, Inc., USA. Unblended clover honey from New Zealand (Batch 120708) was purchased from Caremark SDN BHD, Malaysia. All other reagents used were of analytical grade purity.

2.2. FITC Labelling of BSA. The protein solution $(10 \mathrm{mg}$ $\mathrm{BSA} / \mathrm{mL}$ in $100 \mathrm{mM}$ sodium carbonate buffer, $\mathrm{pH} 9.0$ ) was titrated with increasing volumes of FITC $(20 \mathrm{mg} / \mathrm{mL}$ in absolute ethanol) to achieve an FITC/BSA molar ratio of $20: 1$. The reaction mixture was stirred overnight in dark at $4^{\circ} \mathrm{C}$, followed by dialysis against $60 \mathrm{mM}$ sodium phosphate buffer, pH 7.4, to remove unconjugated FITC. The dialysis was continued with several changes of the buffer until the light absorption of the dialysate at $495 \mathrm{~nm}$ reached a value $<0.003$. The FITC-labelled BSA (FITC-BSA) was concentrated to a final concentration of $13.34 \mathrm{mg} / \mathrm{mL}$ and stored in dark at $4^{\circ} \mathrm{C}$.

2.3. Analytical Procedures. The concentration of FITClabelled BSA as well as FITC to protein molar ratio (F:P molar ratio) was obtained in the same way as described by Hungerford et al. [19]. The concentration of stock urea solution was determined by the method of Pace and Scholtz [20].

2.4. Preparation of Stock Honey and Urea Solutions. Stock honey solution $(60 \%, \mathrm{w} / \mathrm{v})$ was prepared by dissolving $600 \mathrm{~g}$ of honey in $60 \mathrm{mM}$ sodium phosphate buffer, $\mathrm{pH} 7.4$ in a total volume of $1000 \mathrm{~mL}$, and the $\mathrm{pH}$ of the solution was adjusted to $\mathrm{pH} 7.4$ with sodium hydroxide. The stock honey solution was diluted with the above buffer to get the desired honey concentrations, and the solutions were filtered through $0.45 \mu \mathrm{M}$ Millipore filter before use to remove the waterinsoluble components of honey such as wax, pollen, honey comb debris, filth particles, and ash [21].

Stock urea solutions $(11.0 \mathrm{M})$, both in the absence and presence of honey, were prepared by dissolving $67 \mathrm{~g}$ of urea in $60 \mathrm{mM}$ sodium phosphate buffer, $\mathrm{pH} 7.4$, with or without the desired honey concentration to a final volume of $100 \mathrm{~mL}$.

2.5. Fluorescence Spectroscopy. The fluorescence spectra of FITC-BSA were obtained on a Jasco spectrofluorometer, model FP-6500, using a $1 \mathrm{~cm}$ path length cell with a protein concentration of $0.5 \mu \mathrm{M}$ at $25^{\circ} \mathrm{C}$ (unless otherwise stated) upon excitation at $495 \mathrm{~nm}$. The emission spectra were recorded between $500 \mathrm{~nm}$ and $600 \mathrm{~nm}$ and fluorescence signals obtained were corrected using the corresponding honey solutions, prepared in the same way except that buffer was used instead of the protein solution.

2.6. Urea Denaturation. Stock FITC-BSA solution $(200 \mu \mathrm{M})$ was diluted to $20 \mu \mathrm{M}$ with desired volume of stock honey solution or buffer to get a desired concentration of honey. For urea denaturation experiments, different volumes of the buffer were added first to tubes containing a fixed volume $(125 \mu \mathrm{L})$ of the protein solution $(20 \mu \mathrm{M}$ FITC-BSA) followed by the addition of different volumes of the stock urea solution to obtain the desired concentration of urea. The total volume of the solution mixture was $5 \mathrm{~mL}$ and the final concentration of FITC-BSA was $0.5 \mu \mathrm{M}$. The tubes were shaken well and incubated for 12 hours in dark at $25^{\circ} \mathrm{C}$ before spectral measurements. Experiments involving honey were carried out in the same way except that all solutions contained the desired concentration of honey. Each experiment was repeated at least three times and the difference in the reported analytical values was found to lie within $\pm 3 \%$.

Data obtained with FITC fluorescence was transformed into the fraction denatured, $F_{D}$, using the equation

$$
F_{D}=\frac{Y-Y_{N}}{Y_{D}-Y_{N}},
$$

where $Y$ represents the observed variable parameter at a given denaturant concentration and $Y_{N}$ and $Y_{D}$ are the values of the variable characteristic of the native and denatured states, respectively [20]. Values of $Y_{N}$ and $Y_{D}$ were obtained by linear extrapolation of pre- and post-transition zones of the denaturation curve. Values of equilibrium constant, $K_{D}$, and free energy of denaturation, $\Delta G_{D}$, were calculated following equations (2) and (3), respectively:

$$
\begin{gathered}
K_{D}=\frac{F_{D}}{1-F_{D}}, \\
\Delta G_{D}=-R T \operatorname{In} K_{D},
\end{gathered}
$$

where $R$ is the gas constant $\left(1.987 \mathrm{cal} \mathrm{mol}^{-1} \mathrm{~K}^{-1}\right.$ ) and $T$ is the absolute temperature in $\mathrm{K}$. The free energy of stabilization $\left(\Delta G_{D}^{\mathrm{H}_{2} \mathrm{O}}\right)$ with or without different honey concentrations in the absence of urea was obtained from the $Y$-intercept of $\Delta G_{D}$ versus urea concentration plot using least squares analysis, whereas the midpoint of denaturation $\left(C_{m}\right)$ was calculated from the linear regression equation [20].

2.7. Thermal Denaturation. Thermal denaturation studies were carried out on a Jasco spectrofluorometer, model FP6500 equipped with a Protech 632D temperature-controlled circulating water bath. The fluorescence spectra of FITCBSA both in the absence and presence of desired honey concentrations ( $10 \%$ and $20 \%, w / v)$ were recorded in the wavelength range of 500-600 $\mathrm{nm}$ upon excitation at $495 \mathrm{~nm}$ 


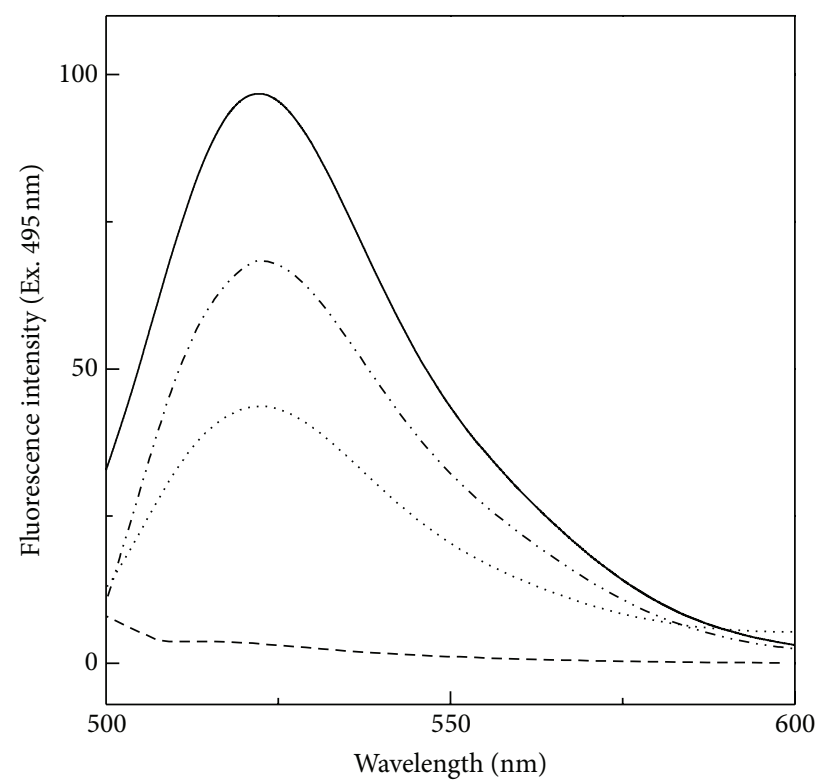

FIGURE 1: Fluorescence spectra of $0.50 \mu \mathrm{M}$ FITC-BSA both in the absence $(-)$ and presence of $10 \%(-\cdots-)$ and $20 \%(\cdots)$ (w/v) honey upon excitation at $495 \mathrm{~nm}$. Fluorescence spectrum of $0.5 \mu \mathrm{M}$ BSA $(--)$ is also shown.

in the temperature range of $25-100^{\circ} \mathrm{C}$ after equilibrating the protein sample for $6 \mathrm{~min}$ at each temperature. The denaturation data were transformed into fraction denatured $\left(F_{D}\right)$ using equation (1) and analysed using a two-state model as described elsewhere [20].

\section{Results and Discussions}

3.1. Influence of Honey on FITC-BSA Fluorescence Spectra. Preliminary studies on the fluorimetric investigation of protein stability in the presence of honey have shown complete quenching of the protein's intrinsic fluorescence in the presence of honey (unpublished data). Such quenching of the protein's intrinsic fluorescence can be ascribed to the presence of various compounds such as flavonoids and polyphenols in the honey, which could act as the quenchers of protein's fluorescence. In view of the unsuitability of intrinsic fluorescence probe to study protein stabilization in the presence of honey, FITC was chosen as an extrinsic fluorescence probe for such studies as both the excitation and emission wavelengths were different from the protein's intrinsic fluorescence excitation and emission wavelengths. Hence, the model protein, BSA, was labelled with FITC following the procedure described in Section 2 and used in the urea and thermal denaturation studies both in the absence and presence of $10 \%$ and $20 \%(\mathrm{w} / \mathrm{v})$ honey. It is important to note that FITC was chemically coupled to the $\varepsilon$-amino group of lysine residues in the FITC-labelled protein molecule [22].

The fluorescence spectrum of FITC-BSA was characterized by the presence of a single emission maxima at $522 \mathrm{~nm}$, spectral characteristic of FITC group (Figure 1). On the other hand, unlabelled BSA did not produce any fluorescence

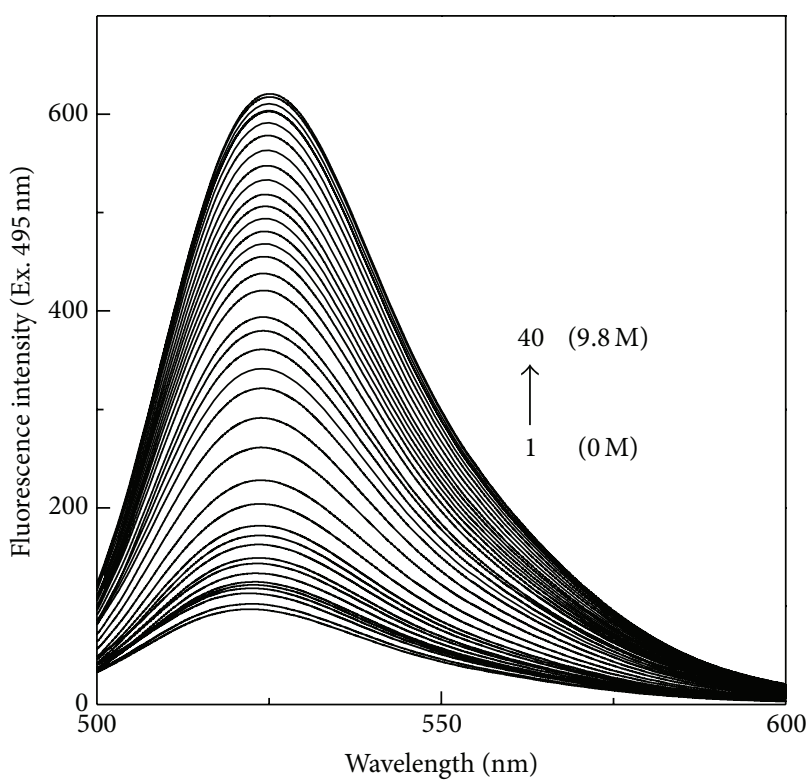

FIGURE 2: Fluorescence spectra of $0.50 \mu \mathrm{M}$ FITC-BSA in the absence and presence of increasing urea concentrations upon excitation at $495 \mathrm{~nm}$. The urea concentrations $(1 \rightarrow 40)$ were $0,0.5,1.0,1.5,2.0$, $2.5,3.0,3.5,3.8,4.0,4.2,4.4,4.6,4.75,4.8,5.0,5.2,5.4,5.6,5.8,6.0$, $6.2,6.4,6.6,6.8,7.0,7.2,7.47 .6,7.8,8.0,8.25,8.5,8.75,9.0,9.3,9.4$, 9.5, 9.7, and $9.8 \mathrm{M}$.

signal within this wavelength range, when excited at $495 \mathrm{~nm}$ (Figure 1). These results suggested that the fluorescence spectrum produced by FITC-BSA was solely due to the presence of FITC group in the labelled BSA without any interference of the protein's intrinsic fluorescence. Hence, FITC fluorescence can be used as a probe to study protein stabilization of a labelled protein in the presence of other proteins in the system. Although a decrease in the fluorescence intensity was observed at the emission maxima in the presence of $10 \%$ and $20 \%(\mathrm{w} / \mathrm{v})$ honey (Figure 1), it was far lesser than the decrease observed in the intrinsic fluorescence showing complete quenching in the presence of $\sim 5 \%(\mathrm{w} / \mathrm{v})$ honey (unpublished data).

3.2. Urea Denaturation of FITC-BSA in the Absence and the Presence of Honey. Figure 2 shows the fluorescence spectra of FITC-BSA both in the absence and presence of increasing urea concentrations. As can be seen from this figure, addition of increasing urea concentrations to FITC-BSA produced a progressive increase in the fluorescence intensity accompanied by a small red shift in the emission maxima. About 6.3fold increase in the fluorescence intensity at $522 \mathrm{~nm}$ along with a $3 \mathrm{~nm}$ red shift in the emission maxima was observed in the presence of $9.8 \mathrm{M}$ urea. Increase in the fluorescence intensity at $522 \mathrm{~nm}$ and the red shift in the emission maxima have also been shown earlier with FITC-BSA in the presence of $6.5 \mathrm{M}$ urea [19]. Since FITC was chemically linked to the lysine residues in BSA molecule; hence, in FITC-BSA, several FITC molecules must be in close proximity with each other in the globular three-dimensional structure as a significant 
TABLE 1: Characteristics of urea denaturation of FITC-BSA in the absence and presence of different honey concentrations as monitored by FITC fluorescence upon excitation at $495 \mathrm{~nm}$.

\begin{tabular}{lcccc}
\hline Protein sample & Transition & & End point $[\mathrm{M}]$ & $\Delta G_{D}^{\mathrm{H}_{2} \mathrm{O}}\left(\mathrm{cal} \mathrm{mol}^{-1}\right)$ \\
\hline FITC-BSA & 4.0 & Midpoint $[\mathrm{M}]$ & 5.7 & 9.3 \\
FITC-BSA + 10\% (w/v) honey & 4.2 & 5.8 & 9.3 & 3400 \\
FITC-BSA + 20\% (w/v) honey & 4.4 & 6.1 & 9.3 & 3700 \\
\hline
\end{tabular}

number of lysine pairs were found separated within $20 \AA$ in the cross-linking and mass spectrometry studies on BSA [23]. Thus, the formation of nonfluorescent dimers due to the association of FITC molecules can account for the concentration quenching in FITC-BSA [24, 25]. Furthermore, resonance energy transfer from excited FITC molecules to a nonfluorescent dimer might have caused further quenching in the fluorescence. Additionally, a small Stokes' shift in fluorescein molecule might have allowed homoenergy transfer [26]. Thus, FITC-BSA seems to be a highly quenched molecule. In view of this, increase in the fluorescence intensity of FITC-BSA upon addition of urea can be explained on the basis of the phenomenon of fluorescence dequenching. Since, urea removes all noncovalent interactions known to stabilize the protein globular structure, transformation of globular structure into a cross-linked random coil in the presence of urea would have separated the proximal FITC groups away from each other and thus caused the release in fluorescence quenching (fluorescence dequenching). Such a release in fluorescence quenching would have been responsible for the increase in the fluorescence intensity observed in the presence of urea. Separation of FITC groups in the ureadenatured protein can also explain the small red shift of $3 \mathrm{~nm}$ in the emission maxima (from $522 \mathrm{~nm}$ to $525 \mathrm{~nm}$ ) observed in the presence of $9.8 \mathrm{M}$ urea. This seems understandable as free FITC is known to display emission maxima at $525 \mathrm{~nm}$ in its fluorescence spectrum [27]. Occurrence of a red shift of $3 \mathrm{~nm}$ in the fluorescence spectra of FITC-BSA in the presence of $9.8 \mathrm{M}$ urea suggested that the microenvironment around the FITC molecule became more polar than that in the native state.

Transformation of the fluorescence intensity values at $522 \mathrm{~nm}$ into fraction denatured, $F_{D}$, at different urea concentrations yielded the denaturation curve shown in Figure 3. Data obtained from urea denaturation experiments of FITCBSA performed in the presence of $10 \%$ and $20 \%(\mathrm{w} / \mathrm{v})$ honey concentrations were transformed in the same way and are also included in Figure 3. The increase in the fluorescence intensity of FITC-BSA upon the addition of urea was found to be smaller at lower urea concentration range $(0.25-4.0 \mathrm{M}$ urea), which was suggestive of small structural perturbation in FITC-BSA within this urea concentration range. A marked increase in the fluorescence intensity was observed between 4.0 $\mathrm{M}$ and $9.3 \mathrm{M}$ urea, indicating major structural alteration in the protein beyond which no significant change in the fluorescence intensity was observed, suggesting completion of the denaturation phenomenon. As can be clearly seen from Figure 3, urea denaturation of FITC-BSA followed a single-step, two-state transition with the start point and the

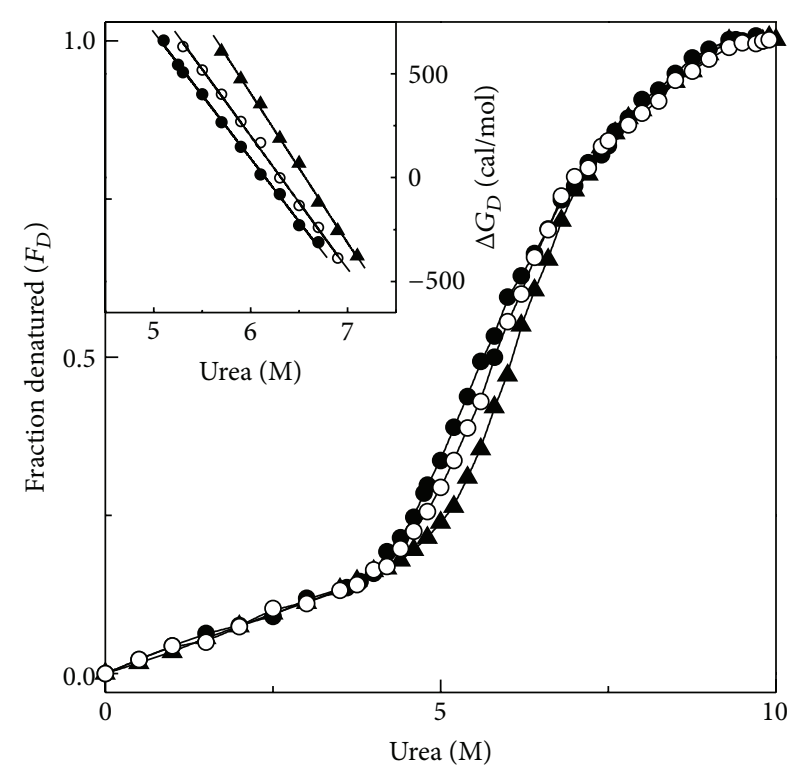

FIGURE 3: Normalized transition curves of urea-induced denaturation of FITC-BSA both in the absence $(\bullet)$ and presence of $10 \%$ (o) and $20 \%(\mathbf{\Delta})(\mathrm{w} / \mathrm{v})$ honey as monitored by FITC fluorescence at $522 \mathrm{~nm}$ upon excitation at $495 \mathrm{~nm}$. Inset shows dependence of $\Delta G_{D}$ of FITC-BSA on urea concentration in the absence $(\bullet)$ and presence of $10 \%(\mathrm{O})$ and $20 \%(\mathbf{\Delta})(\mathrm{w} / \mathrm{v})$ honey.

end point occurring at $\sim 4.0 \mathrm{M}$ and $\sim 9.3 \mathrm{M}$ urea, respectively (Figure 3 and Table 1). The start point observed with FITCBSA was found to be relatively higher compared to the start point obtained in the urea denaturation curve of the unlabelled BSA [16], suggesting greater stability of FITCBSA than unlabelled BSA. However, this change in the stability of FITC-BSA will not affect our conclusions about honey-induced stabilization since the stability of FITCBSA was compared both in the absence and presence of honey. Although urea-induced denaturation of unlabelled BSA showed a two-step, three-state transition with the accumulation of an intermediate state when monitored by intrinsic fluorescence measurements $[16,28]$, the absence of intermediate and single-step, two-state transition observed with FITC fluorescence probe simply reflects the different searching mechanisms of protein denaturation by different probes. Use of several other probes such as 8-anilino-1naphthalene sulfonate (ANS) fluorescence and tryptophan fluorescence also showed a single-step, two-state transition of urea denaturation of serum albumin [29-31]. Yet in another study on urea denaturation of BSA in the presence of $1.0 \mathrm{M}$ 
$\mathrm{KCl}$, a single-step, two-state transition was observed using intrinsic fluorescence as the probe [28]. Therefore, the nature of the transition curve of urea denaturation depends on the probe used.

Urea-induced denaturation curves of FITC-BSA obtained in the presence of $10 \%$ and $20 \%(\mathrm{w} / \mathrm{v})$ honey concentrations were qualitatively similar to that obtained in the absence of honey. However, the transition zone was shifted towards higher urea concentration showing increment in both the start point and the midpoint of transition, suggesting protein stabilization in the presence of different honey concentrations (Figure 3 and Table 1). This shift in the transition curve was found to be concentration dependent, being more pronounced in the presence of $20 \%(\mathrm{w} / \mathrm{v})$ honey concentration. More evidently, the values of the start point and the midpoint of the transition in the presence of $20 \%(\mathrm{w} / \mathrm{v})$ honey were 4.4 $\mathrm{M}$ and $6.1 \mathrm{M}$ compared to $4.2 \mathrm{M}$ and $5.8 \mathrm{M}$, obtained in the presence of $10 \%(\mathrm{w} / \mathrm{v})$ honey (Table 1$)$. Quantitative analysis of the protein stabilization studies in the presence of honey can be made by determining the values of the free energy of stabilization of the protein, $\Delta G_{D}^{\mathrm{H}_{2} \mathrm{O}}$, from the $\Delta G_{D}$ versus urea concentration plots, shown in the inset of Figure 3 , and these values are listed in Table 1. $\Delta G_{D}^{\mathrm{H}_{2} \mathrm{O}}$ of FITC-BSA was found to be $3400 \mathrm{cal} / \mathrm{mol}$ and increased $(29 \%)$ to $4400 \mathrm{cal} / \mathrm{mol}$ in the presence of $20 \%(\mathrm{w} / \mathrm{v})$ honey that further supported the protein stabilization in the presence of honey. Both the shifts in the transition curve, characterized by the increase in the start point and the midpoint of denaturation and increase in the $\Delta G_{D}^{\mathrm{H}_{2} \mathrm{O}}$ value, obtained in the presence of $10 \%$ and $20 \%$ $(\mathrm{w} / \mathrm{v})$ honey, were indicative of protein stabilization of FITCBSA in the presence of honey.

\subsection{Thermal Denaturation of FITC-BSA in the Absence and the} Presence of Honey. In order to study the thermal stabilizing potential of honey, thermal denaturation studies of FITCBSA both in the absence and presence of different honey concentrations (10\% and 20\%, w/v) were performed. Figure 4 shows the fluorescence spectra of FITC-BSA, obtained at different temperatures within the temperature range of 25$100^{\circ} \mathrm{C}$. Similar to the results obtained with urea denaturation studies of FITC-BSA (Figure 2), the increase in temperature also led to an increase in the fluorescence intensity and a small red shift in the emission maxima. Values of the fluorescence intensity at $522 \mathrm{~nm}$ obtained at different temperatures were transformed into fraction denatured, $F_{D}$, as described in Section 2 and are plotted against temperature (Figure 5). Thermal transition curve of FITC-BSA showed no change in the fluorescence intensity in the initial temperature range $\left(25-45^{\circ} \mathrm{C}\right)$, a marked increase within the temperature range $\left(45-95^{\circ} \mathrm{C}\right)$, and no change in the fluorescence intensity beyond $95^{\circ} \mathrm{C}$. Fluorescence data obtained in the presence of $10 \%$ and $20 \%(\mathrm{w} / \mathrm{v})$ honey were transformed in the same way and are shown in Figure 5. Thermal denaturation of FITC-BSA showed a single-step, two-state transition with the occurrence of the start point and the end point at $45^{\circ} \mathrm{C}$ and $95^{\circ} \mathrm{C}$, respectively (Figure 5). The midpoint (melting temperature, $T_{m}$ ) was observed at $69.3^{\circ} \mathrm{C}$. Thermal transition curve of FITC-BSA obtained in the presence of $10 \%$ and $20 \%(\mathrm{w} / \mathrm{v})$

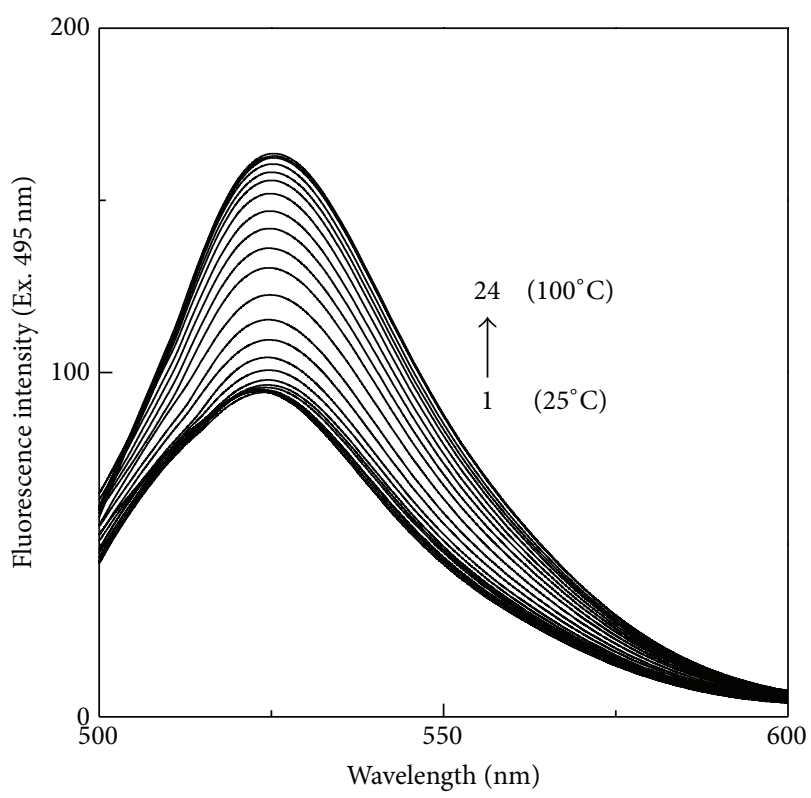

FIGURE 4: Fluorescence spectra of $0.50 \mu \mathrm{M}$ FITC-BSA obtained at increasing temperatures in the range of $25-100^{\circ} \mathrm{C}$ upon excitation at $495 \mathrm{~nm}$. Different temperatures $(1 \rightarrow 24)$ used were: $25,30,35,40$, $45,50,52.5,55,57.5,60,62.5,65,67.5,70,72.5,75,77.5,80,82.5,85$, $90,95,97.5$ and $100^{\circ} \mathrm{C}$.

honey showed a marked shift in the transition curve towards higher temperature. Values of the start point, midpoint, and end point obtained in the thermal transition curve of FITCBSA in the presence of different honey concentrations are given in Table 2. Both start point and midpoint showed an increase in the presence of honey, being higher at $20 \%(\mathrm{w} / \mathrm{v})$ honey concentration (Table 2). Both the shift in the transition curve and increase in the start point and midpoint values of FITC-BSA thermal transition curve observed in the presence of $10 \%$ and $20 \%(\mathrm{w} / \mathrm{v})$ honey were suggestive of honeyinduced FITC-BSA stabilization against temperature.

Determination of $\Delta G_{D}^{25^{\circ} \mathrm{C}}$ was made using $\Delta G_{D}$ versus temperature plots (inset of Figure 5) both in the absence and presence of different honey concentrations. As can be seen from Table 2, the presence of $10 \%$ and $20 \%(\mathrm{w} / \mathrm{v})$ honey in the reaction mixture increased the $\Delta G_{D}^{25^{\circ} \mathrm{C}}$ value from $4400 \mathrm{cal} / \mathrm{mol}$ (for FITC-BSA) to $5500 \mathrm{cal} / \mathrm{mol}$ and $8400 \mathrm{cal} / \mathrm{mol}$, respectively. The enthalpy change of thermal denaturation of FITC-BSA both in the absence and presence of $10 \%$ and $20 \%(\mathrm{w} / \mathrm{v})$ honey, as determined from the van't Hoff plot (Figure 6), also showed significant increase in the $\Delta \mathrm{H}$ value from $41800 \mathrm{cal} / \mathrm{mol}$ for FITC-BSA to $55000 \mathrm{cal} / \mathrm{mol}$ in the presence of $20 \%(\mathrm{w} / \mathrm{v})$ honey (Table 2), suggesting thermal stabilization of FITC-BSA in the presence of honey. Although an increase in $\Delta G_{D}^{\mathrm{H}_{2} \mathrm{O}}$ and $\Delta G_{D}^{25^{\circ} \mathrm{C}}$ of FITC-BSA was noticed in the presence of honey, the increase in $\Delta G_{D}^{25^{\circ} \mathrm{C}}$ was much higher compared to the increase in $\Delta G_{D}^{\mathrm{H}_{2} \mathrm{O}}$ obtained in urea denaturation experiments. In other words, the presence 
TABLE 2: Characteristics of thermal denaturation of FITC-BSA in the absence and presence of different honey concentrations as monitored by FITC fluorescence upon excitation at $495 \mathrm{~nm}$.

\begin{tabular}{|c|c|c|c|c|c|}
\hline \multirow{2}{*}{ Protein sample } & \multicolumn{3}{|c|}{ Transition } & \multirow{2}{*}{$\Delta G_{D}^{25^{\circ} \mathrm{C}}\left(\mathrm{cal} \mathrm{mol}^{-1}\right)$} & \multirow{2}{*}{$\Delta \mathrm{H}\left(\mathrm{cal} \mathrm{mol}^{-1}\right)$} \\
\hline & Start point $\left({ }^{\circ} \mathrm{C}\right)$ & Midpoint $\left({ }^{\circ} \mathrm{C}\right)$ & End point $\left({ }^{\circ} \mathrm{C}\right)$ & & \\
\hline FITC-BSA & 45.0 & 69.3 & 95.0 & 4400 & 41800 \\
\hline FITC-BSA + $10 \%(\mathrm{w} / \mathrm{v})$ honey & 57.5 & 75.0 & 95.0 & 5500 & 51000 \\
\hline FITC-BSA $+20 \%(w / v)$ honey & 62.5 & 82.8 & 95.0 & 8400 & 55000 \\
\hline
\end{tabular}

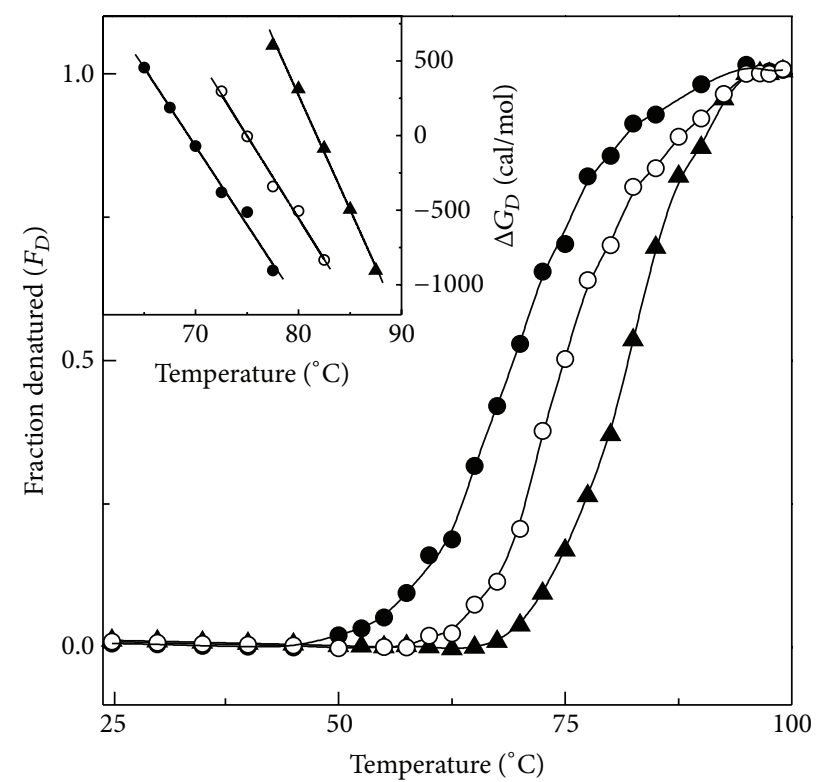

FIGURE 5: Normalized transition curves of thermal-induced denaturation of FITC-BSA both in the absence $(\bullet)$ and presence of $10 \%$

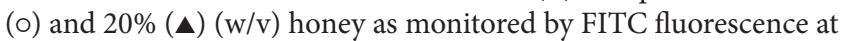
$522 \mathrm{~nm}$ upon excitation at $495 \mathrm{~nm}$. Inset shows dependence of $\Delta G_{D}$ of FITC-BSA on temperature in the absence $(\bullet)$ and presence of $10 \%$ (o) and $20 \%(\boldsymbol{\Delta})(\mathrm{w} / \mathrm{v})$ honey.

of honey in the protein solution offered greater thermal stability to the protein than chemical stability. Such a difference might be attributed to different mechanisms of denaturation as well as different denatured states of the protein, obtained under urea and thermal denaturations [32, 33].

Figure 7 shows the fluorescence spectra of FITC-BSA $\left(\right.$ at $25^{\circ} \mathrm{C}$ ) and thermal-denatured FITC-BSA at $70^{\circ} \mathrm{C}$ both in the absence and presence of $10 \%$ and $20 \%(\mathrm{w} / \mathrm{v})$ honey. There was a significant increase $(\sim 30 \%)$ in the fluorescence intensity at $522 \mathrm{~nm}$ along with $2 \mathrm{~nm}$ red shift in the $70^{\circ} \mathrm{C}$ thermal-denatured FITC-BSA, which were suggestive of protein denaturation. The presence of $10 \%$ and $20 \%(\mathrm{w} / \mathrm{v})$ honey in the reaction mixture led to a significant reversal in the fluorescence intensity towards FITC-BSA fluorescence, being more significant in the presence of $20 \%(\mathrm{w} / \mathrm{v})$ honey. About $\sim 47 \%$ and $\sim 84 \%$ reversals in the fluorescence intensity at $522 \mathrm{~nm}$ were observed in the presence of $10 \%$ and $20 \%$ (w/v) honey, respectively. These results further supported the protein stabilization effect of honey against thermal denaturation of the protein.

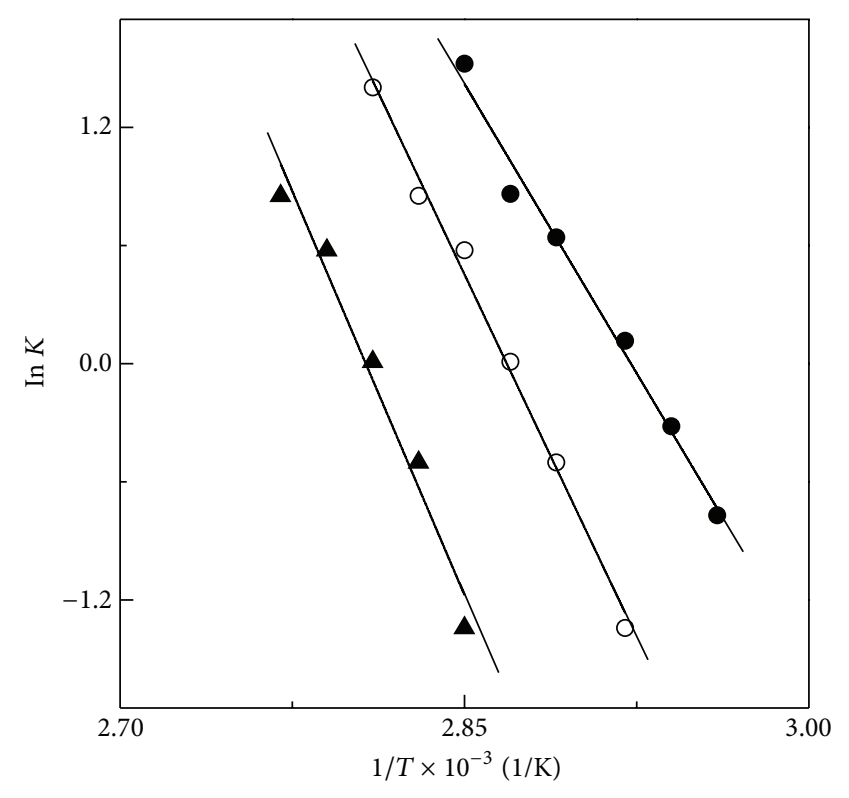

FIGURE 6: van't Hoff plot of thermal denaturation results of FITC-

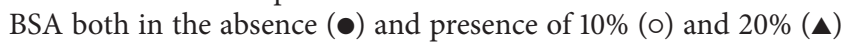
$(\mathrm{w} / \mathrm{v})$ honey, as obtained from the results shown in Figure 5.

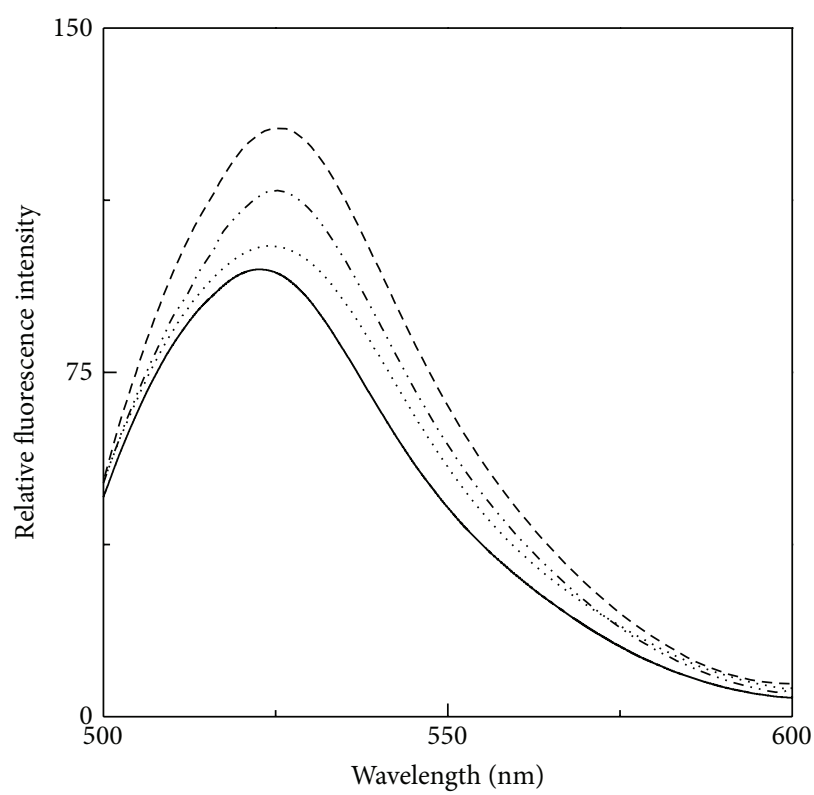

FIgURE 7: Fluorescence spectra of FITC-BSA at $25^{\circ} \mathrm{C}(-)$ and $70^{\circ} \mathrm{C}$ both in the absence (- - ) and presence of $10 \%(-\cdots-)$ and $20 \%(\cdots)$ $(w / v)$ honey. 
High sugar content and the presence of almost all amino acids in honey have rendered it to be an effective protein stabilizer as both of these components are osmolytes whose protein stabilizing potential is well known $[1,11-14,16]$. Different mechanisms have been proposed to explain the osmolyteinduced stabilization of proteins under denaturing conditions [11,34-36]. According to Smith and coworkers [34], addition of osmolytes to aqueous protein solution changes the solvent properties leading to stronger hydrophobic interactions in protein and reduces the hydrogen rupturing potency of vicinity water molecules. On the other hand, both "preferential hydration" and "preferential exclusion" phenomena dominate the osmolyte-induced stabilization mechanism proposed by Timasheff and his group $[10,11,36]$. Moreover, Bolen and Baskakov [35] emphasized the importance of unfavourable solvophobic interactions between osmolyte and polypeptide backbone, which was termed as "osmophobic effect," as the main contributor towards increasing Gibbs free energy. Overall, these mechanisms have suggested the displacement of equilibrium between protein's native state and denatured state towards the native state in presence of osmolyte, thus stabilizing the protein against denaturing conditions.

Due to the presence of different sugars and amino acids in honey, the stabilizing effect observed in the presence of honey would be the additive effect of all the osmolytes present in the honey. As these compounds are known to be present in different honey samples [18], honey samples from different origins are supposed to show the similar protein stabilizing potential. Several earlier reports on osmolyteinduced stabilization of proteins by cosolute mixtures have also suggested the additive effect of the osmolytes $[12,15,16]$. Thus, honey (a bioresource) being a mixture of different osmolytes would have offered greater stabilization than the individual osmolytes.

In conclusion, FITC-BSA was found to be stabilized against urea and thermal denaturations by different honey concentrations. Hence, honey can be used as a protein stabilizer in food related industries.

\section{Acknowledgments}

This work was financially supported by an HIR Grant (F000002-21001) sanctioned by the Ministry of Higher Education, Government of Malaysia and the University of Malaya to Saad Tayyab. The authors gratefully acknowledge the facilities provided by the Institute of Biological Sciences, Faculty of Science, University of Malaya.

\section{References}

[1] C. O. Fagain, "Enzyme stabilization-recent experimental progress," Enzyme and Microbial Technology, vol. 33, no. 2-3, pp. 137-149, 2003.

[2] T. Arakawa, D. Ejima, Y. Kita, and K. Tsumoto, "Small molecule pharmacological chaperones: from thermodynamic stabilization to pharmaceutical drugs," Biochimica et Biophysica Acta, vol. 1764, no. 11, pp. 1677-1687, 2006.

[3] L. R. Singh, N. K. Poddar, T. A. Dar, S. Rahman, R. Kumar, and F. Ahmad, "Forty years of research on osmolyte-induced protein folding and stability," Journal of the Iranian Chemical Society, vol. 8, no. 1, pp. 1-23, 2011.

[4] P. N. Bryan, "Protein engineering of subtilisin," Biochimica et Biophysical Acta, vol. 1543, no. 1, pp. 203-222, 2000.

[5] M. Matsumura, W. J. Becktel, M. Levitt, and B. W. Matthews, "Stabilization of phage T4 lysozyme by engineered disulfide bonds," Proceedings of the National Academy of Sciences of the United States of America, vol. 86, no. 17, pp. 6562-6566, 1989.

[6] B. W. Matthews, H. Nicholson, and W. J. Becktel, "Enhanced protein thermostability from site-directed mutations that decrease the entropy of unfolding," Proceedings of the National Academy of Sciences of the United States of America, vol. 84, no. 19, pp. 6663-6667, 1987.

[7] C. H. I. Ramos and R. L. Baldwin, "Sulfate anion stabilization of native ribonuclease A both by anion binding and by the Hofmeister effect," Protein Science, vol. 11, no. 7, pp. 1771-1778, 2002.

[8] D. A. Estell, "Engineering enzymes for improved performance in industrial applications," Journal of Biotechnology, vol. 28, no. 1, pp. 25-30, 1993.

[9] O. Kirk, T. V. Borchert, and C. C. Fuglsang, "Industrial enzyme applications," Current Opinion in Biotechnology, vol. 13, no. 4, pp. 345-351, 2002.

[10] F. Anjum, V. Rishi, and F. Ahmad, "Compatibility of osmolytes with Gibbs energy of stabilization of proteins," Biochimica et Biophysica Acta, vol. 1476, no. 1, pp. 75-84, 2000.

[11] T. Arakawa and S. N. Timasheff, "Stabilization of protein structure by sugars," Biochemistry, vol. 21, no. 25, pp. 6536-6544, 1982.

[12] N. K. Poddar, Z. A. Ansari, R. K. Singh, A. A. MoosaviMovahedi, and F. Ahmad, "Effect of monomeric and oligomeric sugar osmolytes on $\Delta G_{D}$, the Gibbs energy of stabilization of the protein at different $\mathrm{pH}$ values: is the sum effect of monosaccharide individually additive in a mixture?" Biophysical Chemistry, vol. 138, no. 3, pp. 120-129, 2008.

[13] J. K. Kaushik and R. Bhat, "Why is trehalose an exceptional protein stabilizer? An analysis of the thermal stability of proteins in the presence of the compatible osmolyte trehalose," The Journal of Biological Chemistry, vol. 278, no. 29, pp. 2645826465, 2003.

[14] J. K. Yadav and V. Prakash, "Thermal stability of alpha-amylase in aqueous cosolvent systems," Journal of Biosciences, vol. 34, no. 3, pp. 377-387, 2009.

[15] J. A. Anderson, "Additive effects of alcohols and polyols on thermostability of pepper leaf extracts," Journal of the American Society for Horticultural Science, vol. 132, no. 1, pp. 67-72, 2007.

[16] Y. H. Wong and S. Tayyab, "Protein stabilizing potential of simulated honey sugar cocktail under various denaturation conditions," Process Biochemistry, vol. 47, no. 12, pp. 1933-1943, 2012.

[17] S. Ouchemoukh, P. Schweitzer, M. Bachir Bey, H. DjoudadKadji, and H. Louaileche, "HPLC sugar profiles of Algerian honeys," Food Chemistry, vol. 121, no. 2, pp. 561-568, 2010.

[18] S. Bogdanov, T. Jurendic, R. Sieber, and P. Gallmann, "Honey for nutrition and health: a review," Journal of the American College of Nutrition, vol. 27, no. 6, pp. 677-689, 2008.

[19] G. Hungerford, J. Benesch, J. F. Mano, and R. L. Reis, “Effect of the labelling ratio on the photophysics of fluorescein isothiocyanate (FITC) conjugated to bovine serum albumin," Photochemical and Photobiological Sciences, vol. 6, no. 2, pp. 152-158, 2007. 
[20] C. N. Pace and J. M. Scholtz, "Measuring the conformational stability of a protein," in Protein Structure: A Practical Approach, T. E. Creighton, Ed., pp. 299-321, Oxford University Press, Oxford, UK, 1997.

[21] A. Belay, W. K. Solomon, G. Bultossa, N. Adgaba, and S. Melaku, "Physicochemical properties of the Harenna forest honey, Bale, Ethiopia," Food Chemistry, vol. 141, pp. 3386-3392, 2013.

[22] B. O. de Lumen and A. L. Tappel, "Fluorescein-hemoglobin as a substrate for cathepsin D and other proteases," Analytical Biochemistry, vol. 36, no. 1, pp. 22-29, 1970.

[23] B. X. Huang, H.-Y. Kim, and C. Dass, "Probing threedimensional structure of bovine serum albumin by chemical cross-linking and mass spectrometry," Journal of the American Society for Mass Spectrometry, vol. 15, no. 8, pp. 1237-1247, 2004.

[24] R. F. Chen and J. R. Knutson, "Mechanism of fluorescence concentration quenching of carboxyfluorescein in liposomes: energy transfer to nonfluorescent dimers," Analytical Biochemistry, vol. 172, no. 1, pp. 61-77, 1988.

[25] T. Forster and E. Konig, "Absorption spectra and fluorescence properties of concentrated solutions of organic dyes," Journal of Electrochemistry, Reports the Bunsen Society For Physical Chemistry, vol. 61, no. 3, pp. 344-348, 1957.

[26] J. R. Lakowicz, Principles of Fluorescence Spectroscopy, Springer, New York, NY, USA, 2nd edition, 1999.

[27] F. J. Green, The Sigma-Aldrich Handbook of Stains, Dyes, and Indicators, Sigma Chemical Company, Milwaukee, Wis, USA, 1990.

[28] S. Tayyab, B. Ahmad, Y. Kumar, and M. M. Khan, "Salt-induced refolding in different domains of partially folded bovine serum albumin," International Journal of Biological Macromolecules, vol. 30, no. 1, pp. 17-22, 2002.

[29] Y. Kumar, S. Muzammil, and S. Tayyab, "Influence of fluoro, chloro and alkyl alcohols on the folding pathway of human serum albumin," The Journal of Biochemistry, vol. 138, no. 4, pp. 335-341, 2005.

[30] C. Leggio, L. Galantini, P. V. Konarev, and N. V. Pavel, "Ureainduced denaturation orocess on defatted human serum albumin and in the presence of palmitic acid," Journal of Physical Chemistry B, vol. 113, no. 37, pp. 12590-12602, 2009.

[31] S. Muzammil, Y. Kumar, and S. Tayyab, "Anion-induced stabilization of human serum albumin prevents the formation of intermediate during urea denaturation," Proteins: Structure, Function and Genetics, vol. 40, no. 1, pp. 29-38, 2000.

[32] Y. Tamura and K. Gekko, "Compactness of thermally and chemically denatured ribonuclease A as revealed by volume and compressibility," Biochemistry, vol. 34, no. 6, pp. 1878-1884, 1995.

[33] G. Zoldák, A. Zubrik, A. Musatov, M. Stupák, and E. Sedlák, "Irreversible thermal denaturation of glucose oxidase from Aspergillus niger is the transition to the denatured state with residual structure," The Journal of Biological Chemistry, vol. 279, no. 46, pp. 47601-47609, 2004.

[34] J. F. Back, D. Oakenfull, and M. B. Smith, "Increased thermal stability of proteins in the presence of sugars and polyols," Biochemistry, vol. 18, no. 23, pp. 5191-5196, 1979.

[35] D. W. Bolen and I. V. Baskakov, "The osmophobic effect: natural selection of a thermodynamic force in protein folding," Journal of Molecular Biology, vol. 310, no. 5, pp. 955-963, 2001.

[36] S. N. Timasheff, "Protein-solvent preferential interactions, protein hydration, and the modulation of biochemical reactions by solvent components," Proceedings of the National Academy of
Sciences of the United States of America, vol. 99, no. 15, pp. 97219726, 2002. 

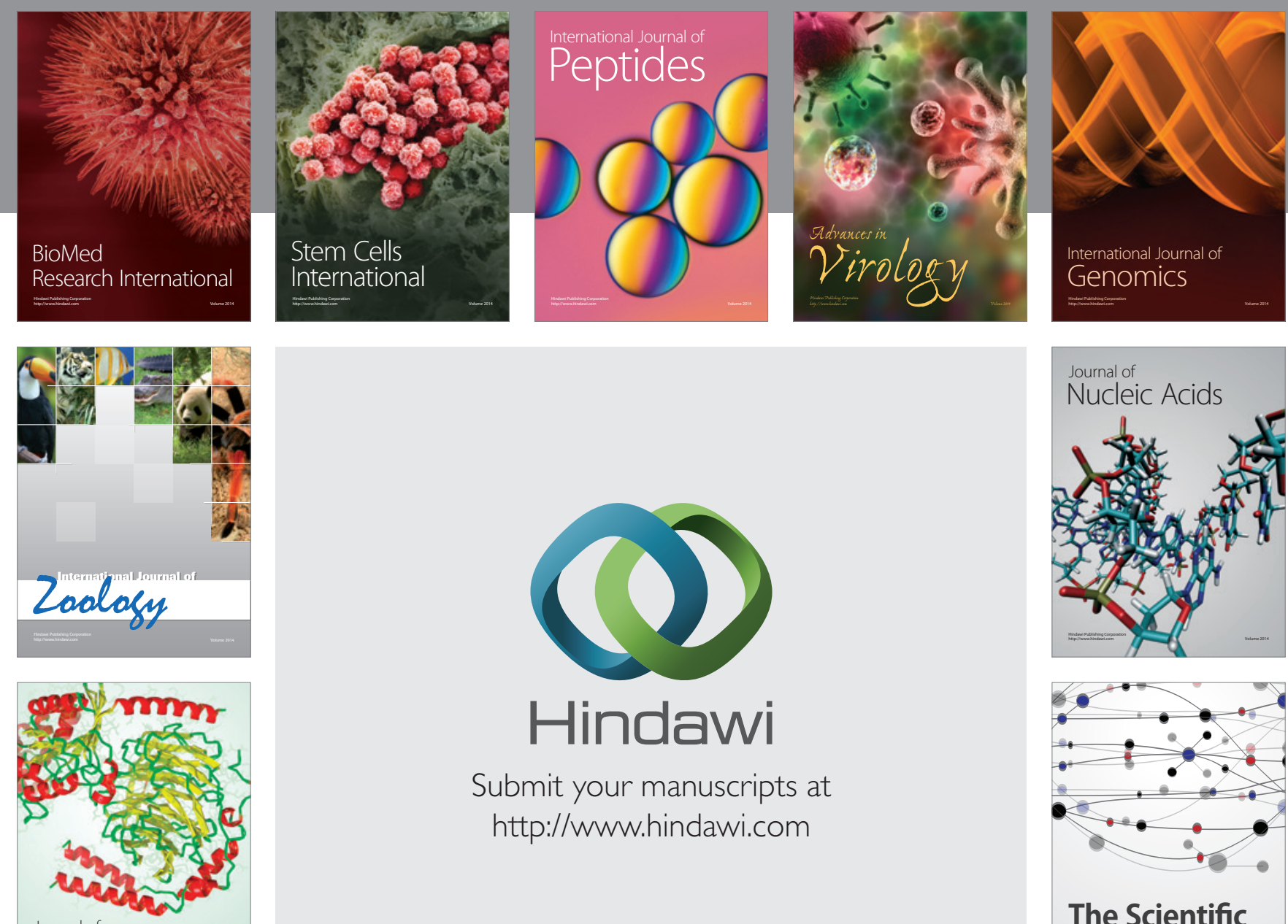

Submit your manuscripts at

http://www.hindawi.com

Journal of
Signal Transduction
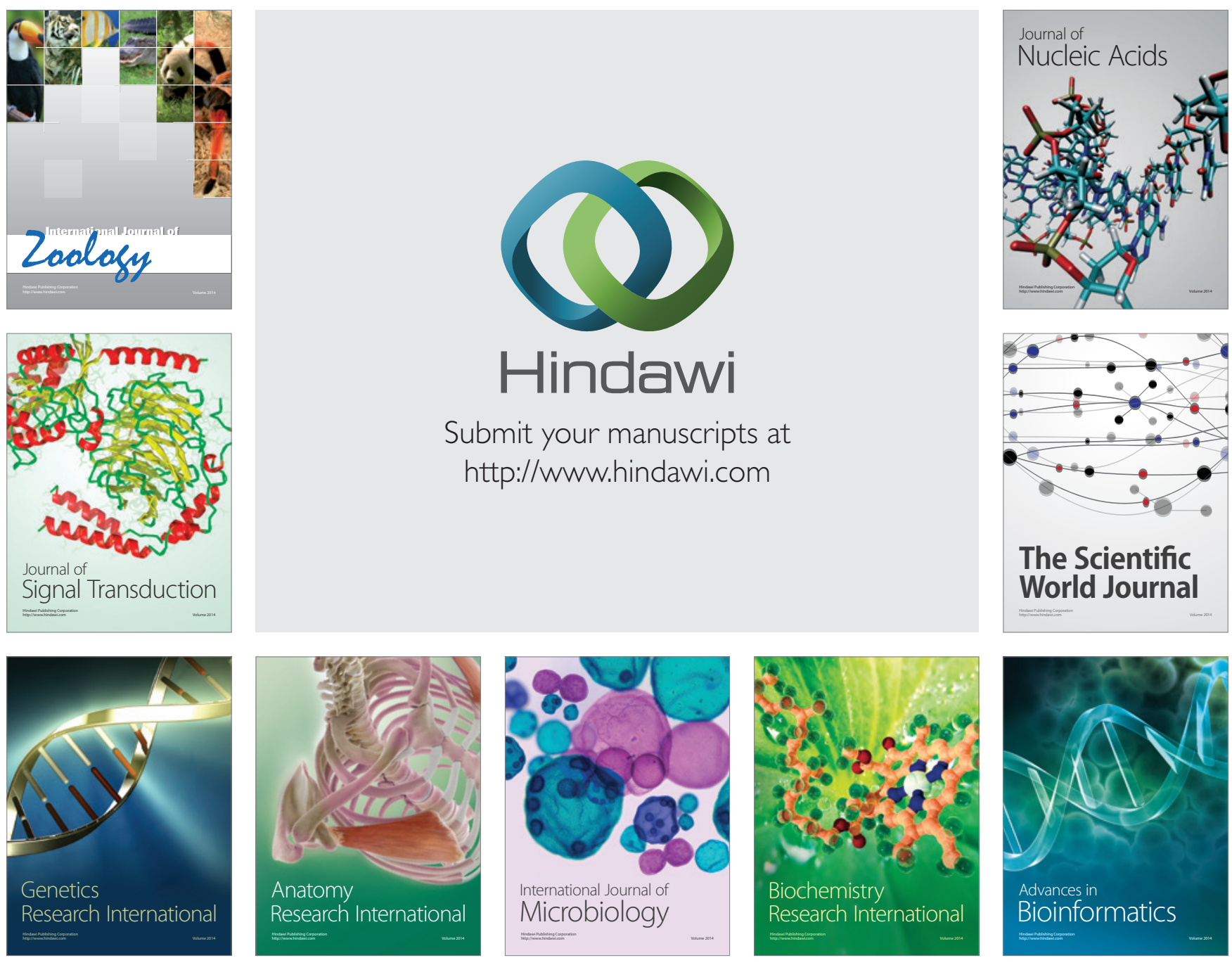

The Scientific World Journal
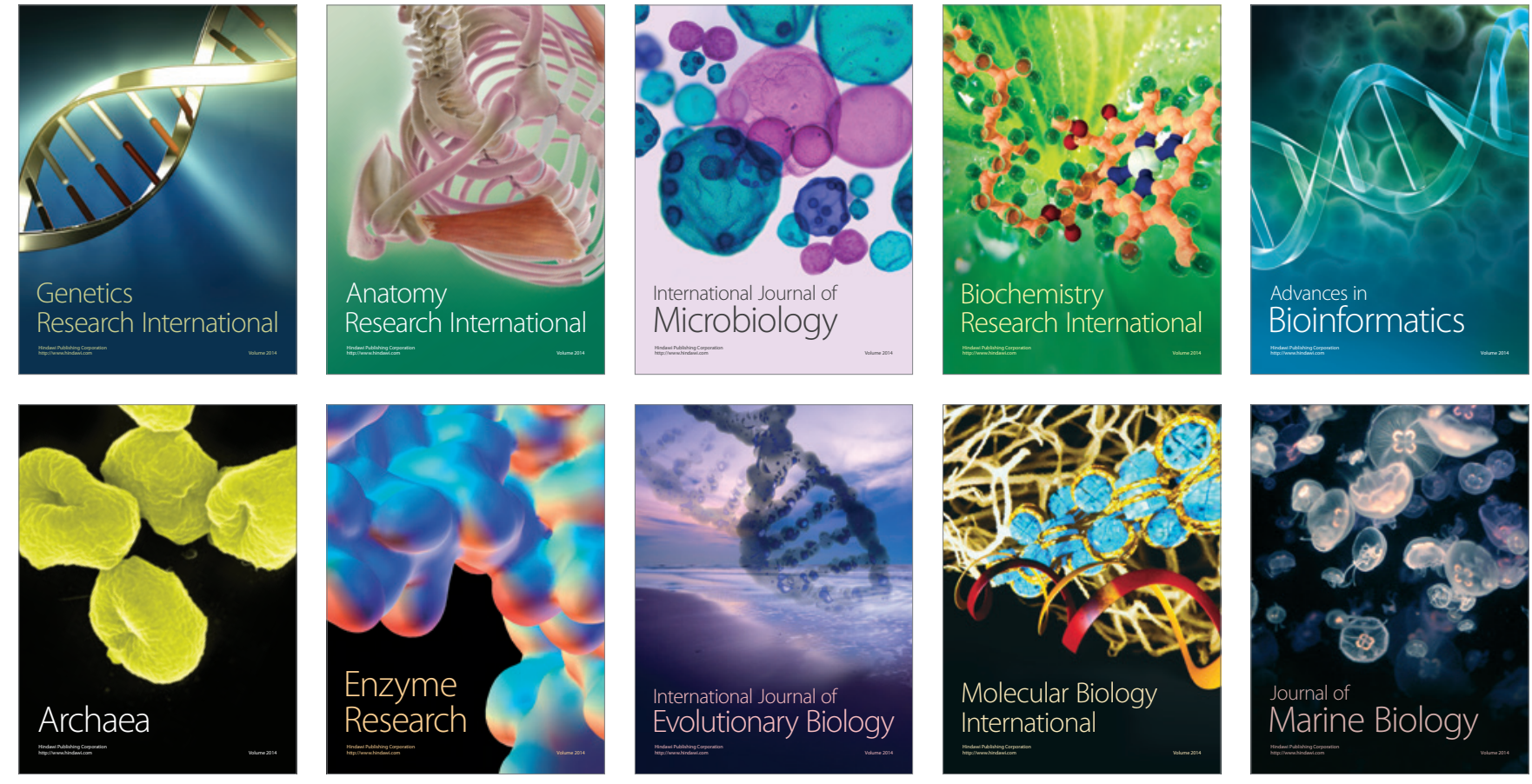